Fixed Point Theory, 19(2018), No. 2, 453-462

DOI: $10.24193 /$ fpt-ro.2018.2.36

http://www.math.ubbcluj.ro/ ${ }_{\text {nodeacj/sfptcj.html }}$

\title{
LEFSCHETZ-TYPE FIXED POINT THEOREMS FOR SPHERIC MAPPINGS
}

\author{
JAN ANDRES* AND LECH GÓRNIEWICZ** \\ *Department of Mathematical Analysis and Applications of Mathematics \\ Faculty of Science, Palacký University \\ 17. Listopadu 12, 77146 Olomouc, Czech Republic \\ E-mail: jan.andres@upol.cz \\ ** Institute of Mathematics, University of Kazimierz Wielki, Weyssenhoffa 11, \\ 85-072 Bydgoszcz, Poland \\ E-mail: gorn@mat.umk.pl
}

Dedicated to Professor Ioan A. Rus on the occasion of his 80th birthday

Abstract. Deterministic as well as random Lefschetz-type fixed point theorems are formulated for multivalued spheric maps on various sorts of special retracts in a Euclidean space.

Key Words and Phrases: Lefschetz theorem, fixed points, spheric mappings, random operators, retracts.

2010 Mathematics Subject Classification: 55M20, 47H10, 47H04, 47H40.

Acknowledgements. The first author was supported by the grant No. 14-06958S "Singularities and impulses in boundary value problems for nonlinear ordinary differential equations" of the Grant Agency of the Czech Republic.

\section{REFERENCES}

[1] J. Andres, L. Górniewicz, Topological Fixed Point Principles for Boundary Value Problems, Kluwer Acad. Publ., Dordrecht, 2003.

[2] J. Andres, L. Górniewicz, Random topological degree and random differential inclusions, Topol. Methods Nonlin. Anal., 40(2012), no. 2, 339-358.

[3] J. Andres, L. Górniewicz, On the Lefschetz fixed point theorem for random multivalued mappings, Libertas Math., 33(2013), no. 1, 69-78.

[4] K. Borsuk, On some metrization of the hyperspace of compact sets, Fund. Math., 41(1954), 168-202.

[5] A. Dawidowicz, Spherical maps, Fund. Math., 127(1987), 187-196.

[6] A. Dawidowicz, Méthodes homologiques dans la théorie des applicationes et des champs de vecteurs sphériques dans les espaces de Banach, Dissertationes Math., Warsaw, Poland, 326(1993).

[7] L. Górniewicz, Homological methods in fixed-point theory of multi-valued maps, Dissertationes Math., 129(1976), Warsaw, Poland.

[8] L. Górniewicz, Topological Fixed Point Theory of Multivalued Mappings, Second Edition, Springer, Berlin, 2006. 
[9] L. Górniewicz, Present state of the Brouwer fixed point theorem for multivalued mappings, Ann. Sci. Math. Québec, 22(1998), 169-179.

[10] L. Górniewicz, Fixed point theorems for multivalued maps of subsets of Euclidean spaces, Bull. Acad. Polon. Sci. Sér. Sci. Math., 27(1979), 111-116.

[11] D. Miklaszewski, A fixed point theorem for multivalued mappings with nonacyclic values, Topol. Methods Nonlin. Anal., 17(2001), 125-131.

[12] D. Miklaszewski, A fixed point conjecture for Borsuk continuous set-valued mappings, Fund. Math., 175(2002), 69-78.

[13] D. Miklaszewski, The role of various kinds of continuity in the fixed point theory of set-valued mappings, Lecture Notes in Nonlinear Analysis, 7(2005), Torun, Poland.

[14] B. O'Neill, A fixed point theorem for multi-valued functions, Duke Math. J., 24(1957), no. 1, 61-62.

[15] R. Skiba, M. Ślosarski, On a generalization of absolute neighbourhood retracts, Topol. Appl., 156(2009), 697-709.

Received: June 7, 2016; Accepted: August 30, 2016. 
